S4A, S4B Fig

\title{
Strain-conserved TFs
}

Sex-independent TFs

A Stat5b

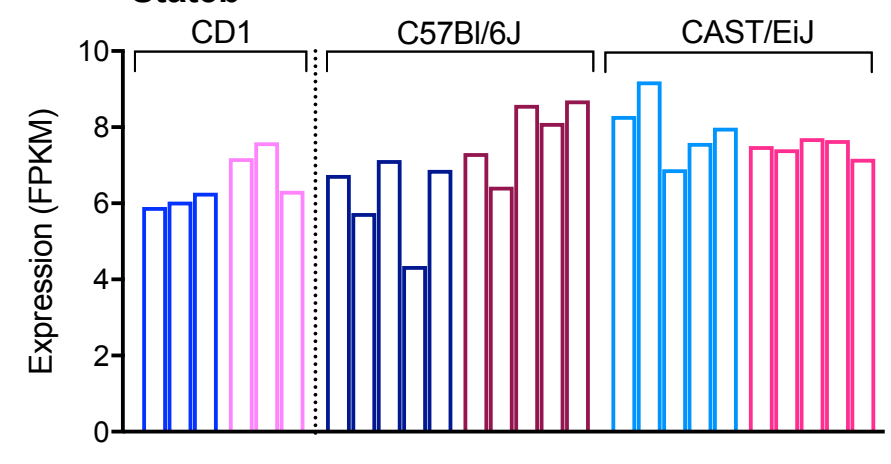

Foxa2
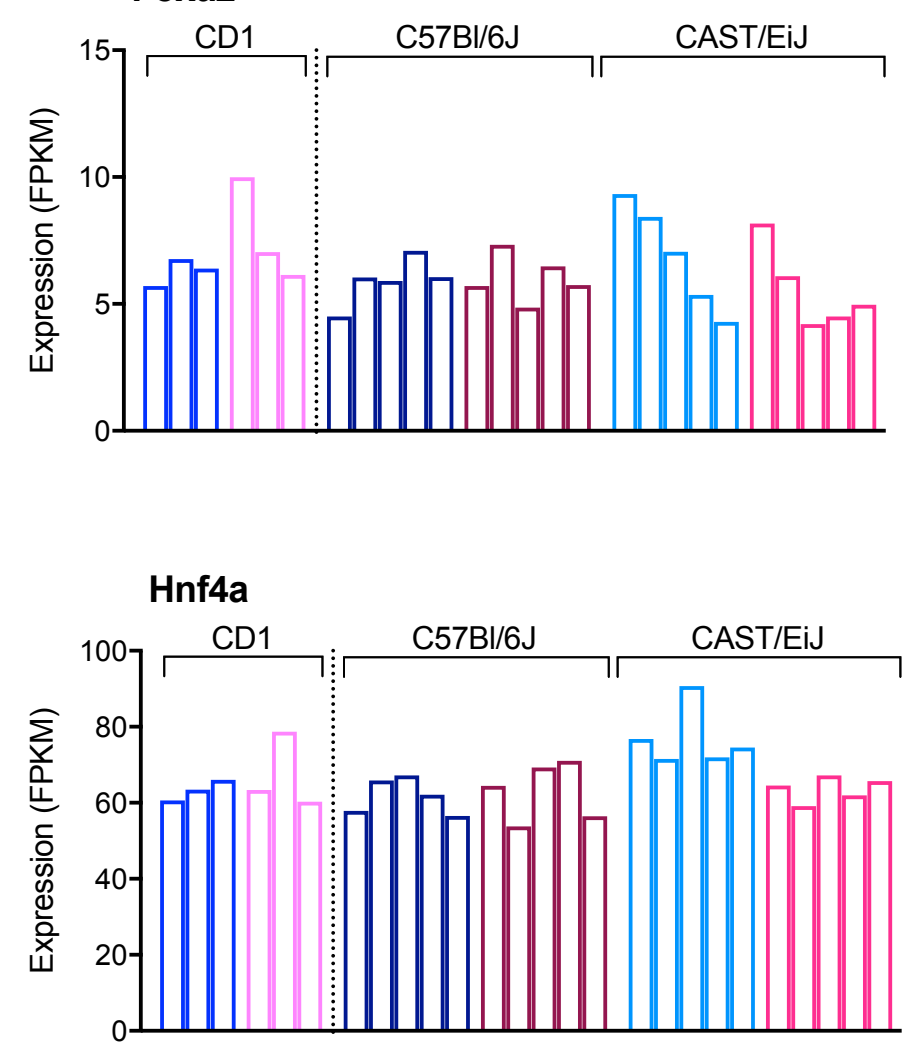

Sex-biased TFs

B cux2

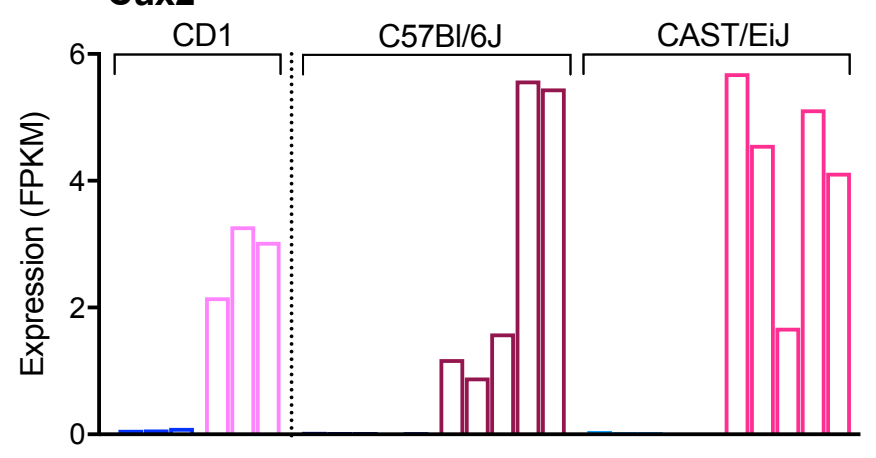

Bcl6

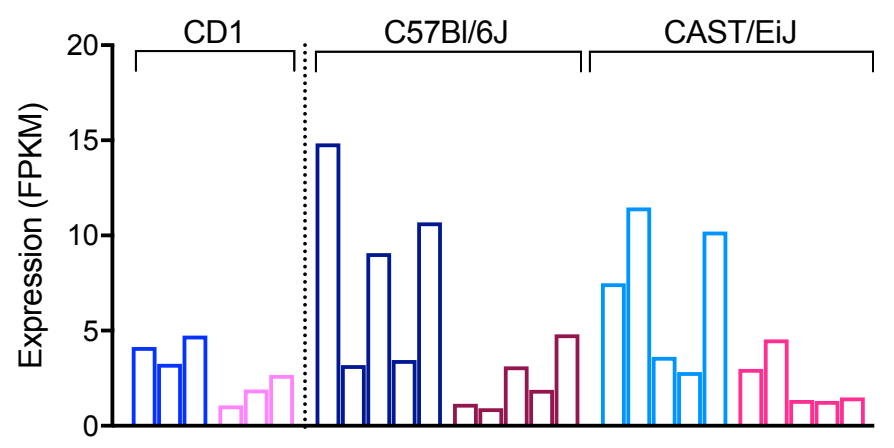

Sall1

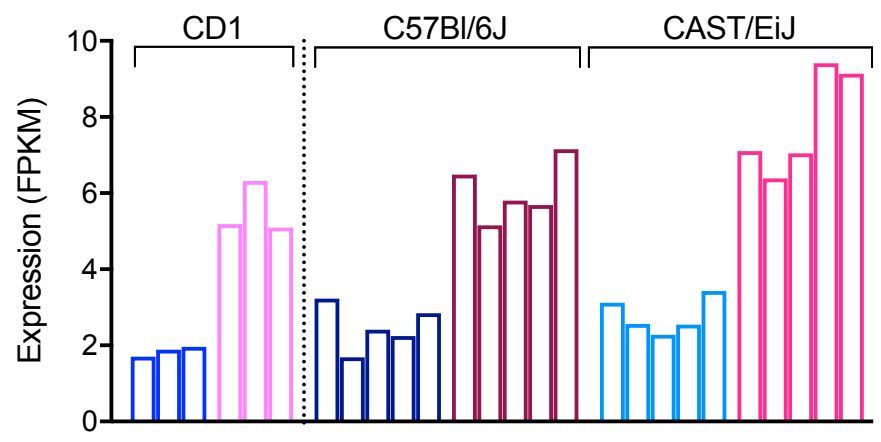

$\square$ Male CD1 $\square$ Male BL6 $\square$ Male CAST

$\square$ Female CD1 $\square$ Female BL6 $\square$ Female CAST 


\section{Strain-dependent TFs}
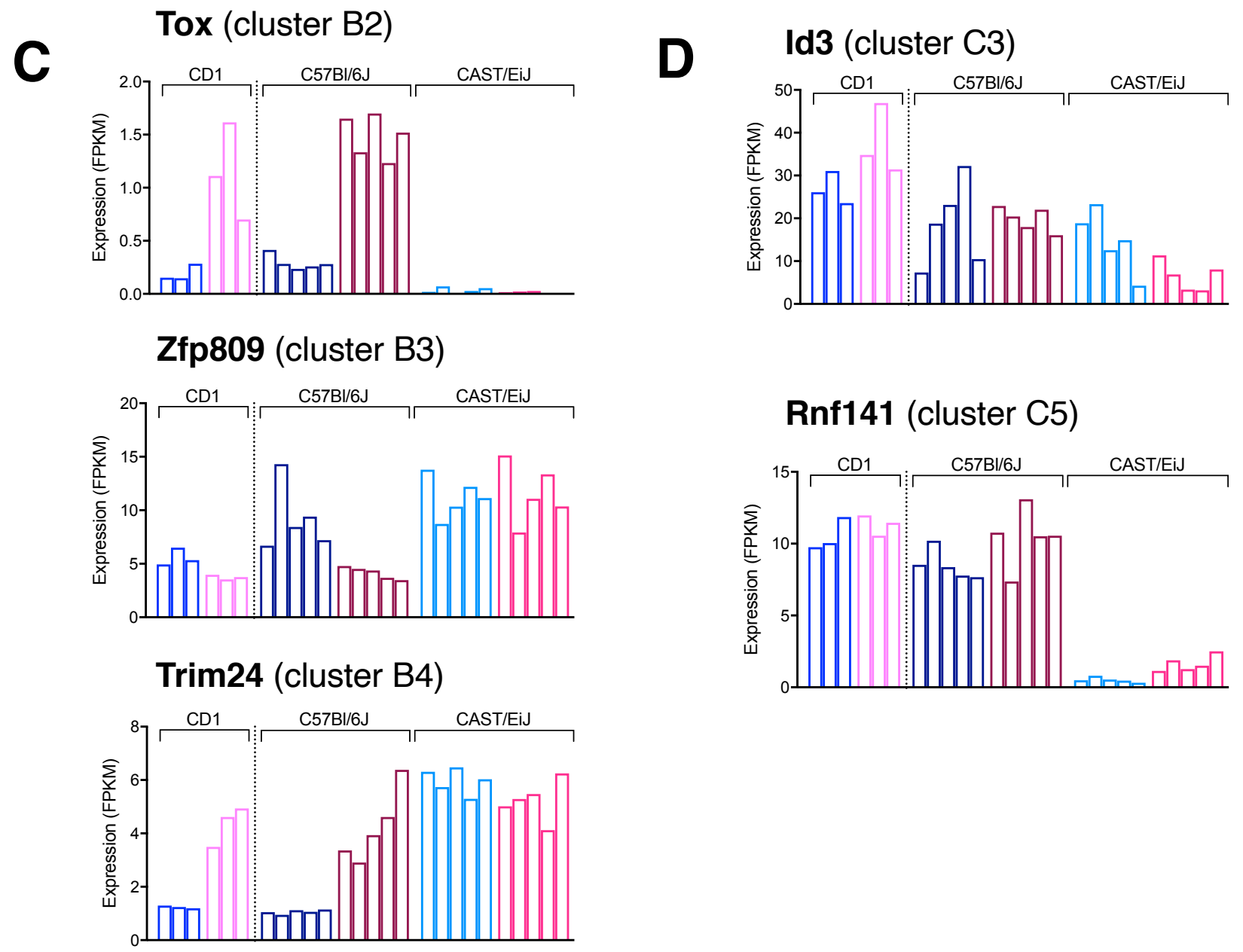

E

\begin{tabular}{|l|rrrrrr|}
\hline & \multicolumn{3}{c|}{ Number of genes } & \multicolumn{2}{c|}{ Microarray (3) } \\
\cline { 4 - 7 } PC-genes (excl. chrY) & C57BL/6J (1) & CAST/EiJ (1) & CD1 (2) & C57BL/6J & CAST/EiJ \\
\hline Sex-biased (standard) & 480 & 392 & 490 & 157 & 104 \\
Sex-biased (strict; FC > 4) & 183 & 149 & 192 & 18 & 14 \\
\multicolumn{1}{l|}{} & & & & & \\
IncRNAs (excl. chrY) & C57BL/6J (1) & CAST/EiJ (1) & CD1 (2) & (1) This study \\
\hline Sex-biased (standard) & 372 & 269 & 336 & (2) GSE98586 \\
Sex-biased (strict; FC > 4) & 208 & 164 & 197 & (3) Jax strainsurvey \\
\hline
\end{tabular}

